\title{
Oligoarginine Peptides, a New Family of Nicotinic Acetylcholine Receptor Inhibitors $\$$
}

\author{
Dmitry S. Lebedev, Elena V. Kryukova, Igor A. Ivanov, Natalia S. Egorova, \\ Nikita D. Timofeev, Ekaterina N. Spirova, Elizaveta Yu. Tufanova, Andrei E. Siniavin, \\ Denis S. Kudryavtsev, Igor E. Kasheverov, Marios Zouridakis, Ramaz Katsarava, \\ Nino Zavradashvili, la lagorshvili, Socrates J. Tzartos, and (1) Victor I. Tsetlin
}

Department of Molecular Neuroimmune Signaling, Shemyakin-Ovchinnikov Institute of Bioorganic Chemistry, Russian Academy of Sciences, Moscow, Russia (D.S.L., E.V.K., I.A.I., N.S.E., N.D.T., E.N.S., E.Y.T., A.E.S., D.S.K., I.E.K., V.I.T.); Department of Neurobiology, Hellenic Pasteur Institute, Athens, Greece (M.Z., S.J.T.); Institute of Molecular Medicine, Sechenov First Moscow State Medical University, Moscow, Russia (I.E.K.); Institute of Chemistry and Molecular Engineering, Agricultural University of Georgia, Kakha Bendukidze University Campus, Tbilisi, Georgia (R.K., N.Z., I.I.); and PhysBio of MePhI, Moscow, Russia (V.I.T.)

Received July 1, 2019; accepted August 26, 2019

\begin{abstract}
Many peptide ligands of nicotinic acetylcholine receptors (nAChRs) contain a large number of positively charged amino acid residues, a striking example being conotoxins RgIA and GeXIVA from marine mollusk venom, with an arginine content of $>30 \%$. To determine whether peptides built exclusively from arginine residues will interact with different nAChR subtypes or with their structural homologs such as the acetylcholinebinding protein and ligand-binding domain of the nAChR $\alpha 9$ subunit, we synthesized a series of $R 3, R 6, R 8$, and $R 16$ oligoarginines and investigated their activity by competition with radioiodinated $\alpha$-bungarotoxin, two-electrode voltageclamp electrophysiology, and calcium imaging. R6 and longer peptides inhibited muscle-type nAChRs, $\alpha 7 \mathrm{nAChRs,} \mathrm{and}$ $\alpha 3 \beta 2 \mathrm{nAChRs}$ in the micromolar range. The most efficient inhibition of ion currents was detected for muscle $\mathrm{nAChR}$ by $\mathrm{R} 16\left(\mathrm{IC}_{50}=157 \mathrm{nM}\right)$ and for the $\alpha 9 \alpha 10$ subtype by R8 and R16 $\left(\mathrm{IC}_{50}=44\right.$ and $120 \mathrm{nM}$, respectively). Since the $\mathrm{R} 8$ affinity for other tested nAChRs was 100-fold lower, R8 appears to be
\end{abstract}

a selective antagonist of $\alpha 9 \alpha 10$ nAChR. For R8, the electrophysiological and competition experiments indicated the existence of two distinct binding sites on $\alpha 9 \alpha 10 \mathrm{nAChR}$. Since modified oligoarginines and other cationic molecules are widely used as cell-penetrating peptides, we studied several cationic polymers and demonstrated their nAChR inhibitory activity.

\section{SIGNIFICANT STATEMENT}

By using radioligand analysis, electrophysiology, and calcium imaging, we found that oligoarginine peptides are a new group of inhibitors for muscle nicotinic acetylcholine receptors (nAChRs) and some neuronal nAChRs, the most active being those with 16 and 8 Arg residues. Such compounds and other cationic polymers are cell-penetrating tools for drug delivery, and we also demonstrated the inhibition of $n A C h R s$ for several of the latter. Possible positive and negative consequences of such an action should be taken into account.

\section{Introduction}

Protein and peptide ligands, namely neurotoxins from snake venom and $\alpha$-conotoxins from Conus sea mollusks, played a key role in the isolation of nicotinic acetylcholine receptors (nAChRs) and in subsequent studies of their structure and function (see reviews by Nirthanan and Gwee, 2004; Tsetlin and Hucho, 2004; Kasheverov et al., 2009a; Changeux,

This work was supported by the Russian Science Foundation [Grants 16-1400215 p (to V.I.T. and D.S.L.) and 18-74-10088 (to D.S.K., E.N.S., A.E.S., and I.I.)], the Russian Foundation for Basic Research [Grants 17-00-0063 and 1804-0084 (to V.I.T. and D.S.L.) and 18-04-01366 (to I.E.K.)], and the Science and Technology Center in Ukraine/Shota Rustaveli Georgia National Science Foundation [Grant 6298 (to R.K. and N.Z.)].

https://doi.org/10.1124/mol.119.117713.

S This article has supplemental material available at molpharm. aspetjournals.org.
2012; Utkin, 2013; Dutertre et al., 2017). To date, muscle-type and neuronal nAChRs, as well as so-called "non-neuronal" nAChRs built with the same subunits as neuronal nAChRs, have been identified. Non-neuronal nAChRs are found in immune system cells and other tissues (Wang et al., 2003; Kawashima et al., 2015; Spindel, 2016). Snake venom neurotoxins interact mainly with muscle nAChRs and with receptors built from $\alpha 7$ or $\alpha 9 \alpha 10$ subunits (Dutertre et al., 2017). $\alpha$-Conotoxins, short neurotoxic peptides from poisonous Conus sea mollusks, appeared in the nAChR research later; yet it is the variety of natural $\alpha$-conotoxins and their numerous synthetic analogs that allows not only accurate discrimination between the muscle and neuronal nAChRs but also identification of various subtypes of the latter (McIntosh et al., 1999; Dutertre et al., 2007, 2017; Azam and McIntosh, 2009;

ABBREVIATIONS: $\alpha$ Bgt, $\alpha$-bungarotoxin; ACh, acetylcholine; AChBP, acetylcholine-binding protein; Apd, $N$-(2-aminoethyl)-1,3-propanediamine; $\mathrm{Cl}$, confidence interval; CP, cationic polymer; CTX, $\alpha$-cobratoxin; HPLC, high-performance liquid chromatography; LBD, ligand-binding domain; MS, mass spectrometry; nAChR, nicotinic acetylcholine receptor; TFA, trifluoroacetic acid. 
Lebbe et al., 2014) and even species selectivity of distinct receptor subtypes (Yu et al., 2018).

There are currently no X-ray or cryoelectron microscopy structures for the nAChR complexes with either $\alpha$-neurotoxins or $\alpha$-conotoxins, and information on the binding surfaces of these compounds is based primarily on the crystal complexes with the acetylcholine-binding proteins (AChBPs) (Bourne et al., 2005; Celie et al., 2005) or with the ligand-binding domains (LBDs) of the $\alpha 1$ or $\alpha 9$ subunits (Dellisanti et al., 2007; Zouridakis et al., 2014). All of these structures demonstrated an important role of positive charges both in agonists, such as carbachol (Celie et al., 2004), and in the abovementioned neurotoxins. To note, there are also many positive charges in azemiopsin, a linear peptide from viper venom that efficiently inhibits muscle nAChRs (Utkin et al., 2012). Interestingly, the addition of positive charges (of Lys or Arg residues, in particular) was previously shown to considerably enhance the affinity of $\alpha$-conotoxins for various nAChR subtypes (Kasheverov et al., 2006, 2011, 2016). In a characteristic environment is the positive charge of nicotine as found recently by cryoelectron microscopy of its complex with the $\alpha 4 \beta 2$ nAChR (Morales-Perez et al., 2016). This study is devoted to the role of Arg residues and was stimulated by the discovery of $\alpha \mathrm{O}$-conotoxin GeXIVA (Luo et al., 2015), which has high selectivity for the $\alpha 9 \alpha 10 \mathrm{nAChR}$, a possible target for the design of novel analgesics (Vincler et al., 2006). This conotoxin was built with 28 amino acid residues; nine are Arg residues and the conotoxin contains the sequence RRRR, so we decided to investigate whether a peptide built exclusively with Arg residues would be active against nAChRs.

A series of Arg oligomers was synthesized and their action was analyzed by radioligand competition assay on several nAChR subtypes and on nAChR models, namely on AChBPs from Aplysia californica and Lymnaea stagnalis and a LBD of the $\alpha 9$ subunit. Interestingly, peptides like $\mathrm{R} 8$ as such or in modified form (e.g., including aromatic residues) (Nakase et al., 2008) are used for targeted drug and gene delivery through cell membranes (Jiang et al., 2011; Biswas et al., 2013). This is why we supplemented our work by oligoarginines with added tryptophan residues. Functional activity of the synthesized peptides was then tested by electrophysiology and calcium imaging. Structures of all investigated ligands are given in Fig. 1 and all methods, receptors, and models used are listed in Table 1.

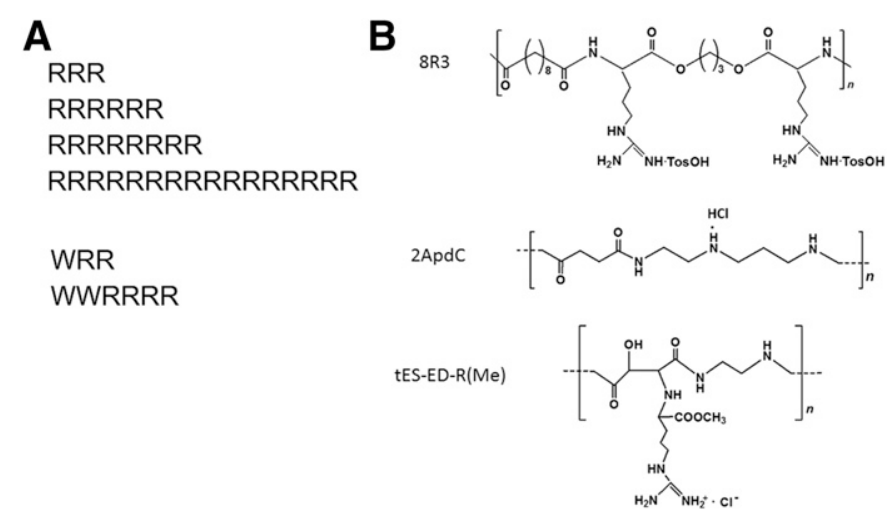

Fig. 1. (A) Sequences of all studied peptides. (B) Structures of investigated CPs.
With regard to oligoarginines, we should add that cationic polymers (CPs) are an effective, biodegradable instrument for intracellular delivery of nucleic acids and other negatively charged molecules. CPs have notable potential for use in gene therapy and drug delivery (Zavradashvili et al., 2019). All CPs have a cationic nature and some contain arginine residues. This is why we performed a binding assay and functional tests on several recently synthesized CPs (Memanishvili et al., 2014; Zavradashvili et al., 2019) and demonstrated their effects on nAChRs. Thus, our results show that oligoarginines are a new group of nAChR inhibitors that may be useful in nAChR research, and this property should be taken into account when applying oligoarginines and related compounds for drug delivery.

\section{Materials and Methods}

Solid-Phase Synthesis of Peptides. A polystyrene resin with a 2-chlorotrityl chloride handle, Fmoc-protected amino acids, and diisopropylcarbodiimide were from Iris Biotech. 4-Methylpiperidine was from Acros Organics. Oxima Pure was from EMD Chemicals. Trifluoroacetic acid (TFA) was from Solvay S.A. CLEAR-OX resin was from Peptides International. Acetonitrile was a gradient grade and was obtained from Biosolve. All other reagents and solvents were purchased from a local manufacturer and used without additional purification.

Peptide synthesis was carried out using a MultiSynTech Syro I automatic peptide synthesizer. Preparative purification was carried out on a Gilson high-performance liquid chromatography (HPLC) system (333/334 pump with 215 liquid handler and 155 UV detector, set at 210 and $280 \mathrm{~nm}$ ). Peptides were eluted with an $\mathrm{H}_{2} \mathrm{O}$-acetonitrile gradient with $0.1 \%$ TFA. HPLC-mass spectrometry (MS) analysis was performed using a Thermo Finnigan LCQ Deca XP ion trap instrument with a Thermo Accela ultra-performance liquid chromatography system equipped with a Waters Atlantis T3 column (C18 $150 \times 2 \mathrm{~mm}, 3 \mu \mathrm{m})$. Detection was achieved with a UV-visible DAD detector and full scan MS (positive electrospray ionization mode, 150-2000 a.u.).

C-terminal amino acid was attached to the 2-chlorotrityl chloride-activated resin in the presence of Huenig's base for 2 hours. Peptide assembly was performed by Fmoc methodology using diisopylcabodiimide activation with Oxima Pure as a nucleophilic additive. A 10-fold excess of amino acids was used within a 2-hour condensation time. After synthesis, the protected peptidyl-polymer was washed with diethyl ether and then dried and treated with a 150:4:3:0.5 (weight proportion) $\mathrm{TFA} /$ dithiothreitol/ $\mathrm{H}_{2} \mathrm{O} /$ triisopropylsilane mixture. Fifteen milliliters of the mixture was applied to $1 \mathrm{~g}$ peptidyl-polymer for 2 hours. The solution was then filtered out, and the dry peptide was precipitated with a 10 -fold volume of diethyl ether and held at $4^{\circ} \mathrm{C}$ for 8 hours. The precipitated peptide was centrifuged, washed three times with diethyl ether, and then dried under vacuum. Crude peptide was purified by HPLC in a linear gradient of acetonitrile from $0 \%$ to $20 \%$ on a Silasorb-C18 column (5u $25 \times 250 \mathrm{~mm}$ ). After purification, the desired fractions were lyophilized and analyzed by matrix-assisted laser desorption/ ionization-MS analysis using the Ultraflex TOF/TOF time-of-flight mass spectrometer (Bruker Daltonics). A solution of 2,5-dihydroxybenzoic acid (20 mg/ml, $50 \%$ acetonitrile in $0.1 \% \mathrm{TFA}$ ) was used as a matrix. The sample was applied to an MTP 384 target plate ground steel TF target (Bruker Daltonics) by a dried drop method. The samples were desorbed by irradiation with a nitrogen laser $(337 \mathrm{~nm}$ wavelength) operating at a frequency of $50 \mathrm{~Hz}$. Analyses of the obtained mass spectrometric data were performed using the FlexAnalyses 3.0 software package (Bruker Daltonics). All measured masses of peptides were in a good accordance with the calculated masses. 
TABLE 1

All methods, receptors, and models used in this study

\begin{tabular}{lll}
\hline Method & \multicolumn{1}{c}{ nAChR Type } & \multicolumn{1}{c}{ Model } \\
\hline Competitive radioligand assay & $\alpha 1_{2} \beta 1 \gamma \delta$ muscle type & Membranes of T. californica ray electric organ \\
& Human $\alpha 7$ & GH4C1 cells \\
& Human $\alpha 9$ & LBD \\
& AChBP & L. stagnalis \\
& A. californica \\
Two-electrode voltage-clamp electrophysiology & Mouse $\alpha 1_{2} \beta 1 \varepsilon \delta$ muscle & X. laevis oocytes \\
& Human $\alpha 9 \alpha 10$ & \\
Calcium imaging & Human $\alpha 3 \beta 2$ & Neuro2a cells \\
\hline
\end{tabular}

Synthesis of CPs. The R-based cationic poly(ester amide) 8R3, composed of sebacic acid (8), arginine (R), and 1,3-propanediol (3), was synthesized as $p$-toluenesulfonic acid ( $\mathrm{Tos} \mathrm{OH})$ salt by solution polycondensation of di-p-toluenesulfonic acid salt of bis-(L-arginine)-1,3propylene diester with activated diester di-p-nitrophenyl sebacate (Memanishvili et al., 2014). Molecular mass characteristics of the polymer were as follows: molecular mass $=13.10 \mathrm{kDa}, \mathrm{Mn}=5.80 \mathrm{kDa}$, and $Ð=2.26$ (gel permeation chromatography in hexafluoroisopropanol).

The R-attached cationic polyamide $t$ ES-ED-R(Me) was synthesized as hydrochloric acid salt by a two-step/one-pot synthesis consisting of in situ interaction of L-arginine methylester dihydrochloride $[\mathrm{R}(\mathrm{Me}) \cdot 2 \mathrm{HCl}]$ with the intermediate polymer poly(ethylene epoxysuccinimide) ( $t$ ES-ED), which was formed at the first step of the onepot procedure after solution polycondensation of the di-p-nitrophenyl ester of trans-epoxy-succinic acid (NtES) with the di-p-toluenesulfonic acid salt of ethylenediamine (ED.2TosOH) in the presence of triethylamine as a $p$-toluensulfonic acid acceptor. The degree of transformation of $t$ ES-ED after its interaction with $\mathrm{R}(\mathrm{Me}) 2 \mathrm{HCl}$ in the presence of triethylamine as an $\mathrm{HCl}$ acid acceptor was 75\% (Zavradashvili et al., 2014). Molecular mass characteristics of the polymer were as follows: molecular mass $=19.40 \mathrm{kDa}, \mathrm{Mn}=$ $5.01 \mathrm{kDa}$, and $Ð=3.88$. The molecular mass of this polymer was also determined by dynamic light scattering within the concentration range of $10-20 \mathrm{mg} / \mathrm{ml}$ and was $21.60 \mathrm{kDa}$, which coincides well with the HPLC data.

The cationic polyamide $2 \mathrm{ApdC}$ ( $\mathrm{R}$-free) composed of succinic acid (2) and $N$-(2-aminoethyl)-1,3-propanediamine (Apd) was synthesized as hydrochloride salt $(\mathrm{C})$ by solution polycondensation of trihydrochloric acid salt of triamine Apd (ApdC3) with activated diester di- $p$ nitrophenyl succinate (NSu) (Zavradashvili et al., 2019). Molecular mass characteristics of the polymer were as follows: molecular mass = $8.34 \mathrm{kDa}, \mathrm{Mn}=2.80 \mathrm{kDa}$, and $Ð=2.2697$ (gel permeation chromatography in hexafluoroisoparpanol).

Analysis of Competition of Arginine-Containing Peptides and CPs with Radioiodinated $\alpha$-Bungarotoxin for Binding to $\alpha 9$ LBD, A. californica and L. stagnalis AChBPs, Torpedo californica nAChR, and Human $\alpha 7$ nAChR. For competition binding assays, suspensions of membranes from the electric organ of the $T$. californica ray [1.25 $\mathrm{nM} \alpha$-bungarotoxin ( $\alpha$ Bgt) binding sites], human $\alpha 7$ nAChR-transfected GH4C1 cells (0.4 nM $\alpha$ Bgt binding sites), or heterologously expressed A. californica and L. stagnalis AChBPs (150 and $2.5 \mathrm{nM} \alpha$ Bgt binding sites, respectively) were incubated in $50 \mu \mathrm{l}$ binding buffer ( $20 \mathrm{mM}$ phosphate buffer, $\mathrm{pH} 7.0$, containing $1 \mathrm{mg} / \mathrm{ml}$ bovine serum albumin) for 90 minutes with various amounts of peptides or $\mathrm{CPs}$, followed by an additional 5 -minute incubation with $0.1-0.2 \mathrm{nM}^{125} \mathrm{I}$-labeled $\alpha \operatorname{Bgt}(500 \mathrm{Ci} / \mathrm{mmol}$ ). The membranes and cell suspensions were applied to glass GF/C filters (Whatman) pretreated with $0.3 \%$ polyethylenimine. The samples were then washed $(3 \times 4 \mathrm{ml})$ with $20 \mathrm{mM}$ cold Tris-HCl buffer, $\mathrm{pH} 8.0$, containing $0.1 \mathrm{mg} / \mathrm{ml}$ bovine serum albumin and bound radioactivity was measured with a Wallac 1470 Wizard Gamma Counter (PerkinElmer). Ten microliters of $\mathrm{Ni}^{2+}$-NTA-agarose was added to the AChBP samples; after an additional 5-minute incubation, suspensions were filtered and washed and bound radioactivity was measured as described above. For the human $\alpha 9$ extracellular domain, competition experiments were carried out with $100 \mathrm{nM} \alpha 9$ extracellular domain and different amounts of the ligands as described for AChBPs. Nonspecific ${ }^{125} \mathrm{I}-\alpha$ Bgt binding was determined in the presence of 200 -fold excess of $\alpha$-cobratoxin.

Since the solubility of oligoarginine peptides and CPs depends on the buffer $\mathrm{pH}$, all binding experiments were carried out in $20 \mathrm{mM}$ phosphate buffer, $\mathrm{pH}$ 7.0. All further functional experiments (calcium imaging, voltage-clamp electrophysiology) were performed in HEPES buffers with $\mathrm{pH}$ 7.4-7.6. Under these conditions, the peptides were soluble up to $100 \mu \mathrm{M}$ and had a positive charge. CPs also did not show any signs of precipitation to $100 \mathrm{mg} / \mathrm{l}$ under these conditions.

Plasmids and RNA Synthesis. Human $\alpha 7 \mathrm{nAChR}$ cDNA in pCEP4 vector and mouse muscle $\alpha 1_{2} \beta 1 \varepsilon \delta$ nAChR subunit sequences cloned in pRBG4 vector were used. Human $\alpha 9, \alpha 10, \alpha 3$, and $\beta 2$ RNAs were derived from pT7TS with the respective inserts. Plasmid constructs of human nAChR $\alpha 9, \alpha 10, \alpha 3$, and $\beta 2$ subunits were linearized with $\mathrm{XbaI}$ restriction enzymes (NEB). mRNAs were transcribed in vitro using the T7 mMESSAGE mMachine (Ambion) and SP6 was prepared using SP6 mMESSAGE mMACHINE highyield capped RNA transcription kits (Ambion). Transcribed mRNA was polyadenylated using the poly(A) tailing kit (Ambion).

Two-Electrode Voltage-Clamp Analysis of Peptide Interaction with Mouse Muscle, Human $\alpha 3 \beta 2$, and $\alpha 9 \alpha 10$ nAChRs. Xenopus laevis frogs were fed twice a week and maintained according to supplier recommendations (Nasco; https://www.enasco. com/page/xen_care). All appropriate actions were taken to minimize animal discomfort and were carried out in accordance with the World Health Organization's International Guiding Principles for Biomedical Research Involving Animals, under IACUC approval (protocol number 251/2018 26.02.18). Oocytes were removed from mature, anesthetized $X$. laevis frogs by dissecting the abdomen and removing the necessary amount of ovarium. Stage V to VI $X$. laevis oocytes were defolliculated with $2 \mathrm{mg} / \mathrm{ml}$ collagenase Type I (Life Technologies) at room temperature $\left(21-24^{\circ} \mathrm{C}\right)$ for 2 hours in Barth's solution composed of $88.0 \mathrm{mM} \mathrm{NaCl}, 1.1 \mathrm{mM} \mathrm{KCl}, 2.4 \mathrm{mM} \mathrm{NaHCO}_{3}, 0.8 \mathrm{mM} \mathrm{MgSO}_{4}$, and $15 \mathrm{mM}$ HEPES-NaOH at $\mathrm{pH}$ 7.6. Oocytes were injected with $9.2 \mathrm{ng}$ human nAChR $\alpha 9$ and $\alpha 10$ cRNA (in a 1:1 ratio), human nAChR $\alpha 3$ and $\beta 2$ cRNA (in a $1: 1$ ratio), or $10.8 \mathrm{ng}$ plasmid DNA, containing mouse muscle $\alpha 1, \beta 1, \delta$, and $\varepsilon$ subunit sequences (in a 1:1:1:1 ratio).

Oocytes were incubated at $18^{\circ} \mathrm{C}$ in Barth's solution supplemented with $40 \mu \mathrm{g} / \mathrm{ml}$ gentamicin and $100 \mu \mathrm{g} / \mathrm{ml}$ ampicillin for 4 days $(\alpha 9 \alpha 10)$ or 2 days (muscle and $\alpha 3 \beta 2$ ) before electrophysiological recordings. Recordings were performed using a Turbo TEC-03X amplifier (Npi Electronic) and WinWCP recording software (University of Strathclyde). We used electrodes containing $3 \mathrm{M} \mathrm{KCl}$ with a resistance of $\sim 0.1$ megaohms. Membrane potential was clamped at $-60 \mathrm{mV}$.

Peak current amplitudes of acetylcholine (ACh)-induced responses were measured before ( $30 \mu \mathrm{M}$ ACh alone) and after preincubation of oocytes with the tested peptides, followed by application of $30 \mu \mathrm{M}$ $\mathrm{ACh} /$ peptide mixture. The ratio between these two measurements was used to assess the activity.

The voltage-current relationship experiment was performed with a 50-millisecond voltage ramp and 5-minute intervals between measurements. All ramps were recorded 3 seconds after application of $10 \mu \mathrm{M}$ ACh or $10 \mu \mathrm{M} \mathrm{ACh} / 0.12 \mu \mathrm{M}$ R8 mixture in the plateau phase 
of response. All inhibitors ( $1 \mu \mathrm{M}$ cobratoxin or $0.12 \mu \mathrm{M}$ R8) were preincubated with oocytes for 5 minutes before recording.

Cell Line Culture and Transfection. Mouse neuroblastoma Neuro2a cells were cultured in Dulbecco's modified Eagle's medium (Gibco) supplemented with $10 \%$ fetal bovine serum (Sigma). All media were supplemented with $1 \times$ penicillin/streptomycin (Sigma) and cultured at $37^{\circ} \mathrm{C}$ in an atmosphere of $5 \% \mathrm{CO}_{2}$.

Neuro2a cells were transiently transfected with plasmids $\alpha 7$ nAChR-pCEP4, Ric3-pCMV6-XL5 (OriGene), and pCase12-cyto vector (Evrogen) utilizing the Lipofectamine transfection protocol (Invitrogen). Transfected cells were grown in Dulbecco's modified Eagle's medium (Paneco) supplemented with $10 \%$ fetal bovine serum (PAA Laboratories) on black 96 -well plates (Corning) at $37^{\circ} \mathrm{C}$ in a $\mathrm{CO}_{2}$ incubator for 72 hours.

Calcium Imaging Analysis on the Neuroblastoma Neuro2a Cell Line Expressing Human $\alpha \mathbf{7}$ AChR. Growth medium was removed and cells were washed with external buffer containing $140 \mathrm{mM} \mathrm{NaCl}, 2 \mathrm{mM} \mathrm{CaCl} 2,2.8 \mathrm{mM} \mathrm{KCl}, 4 \mathrm{mM} \mathrm{MgCl}_{2}, 20 \mathrm{mM}$ HEPES, and $10 \mathrm{mM}$ glucose, $\mathrm{pH}$ 7.4. Intracellular calcium concentration increase $\left[\mathrm{Ca}^{2+}\right]$ i measurements were performed in external buffer containing $10 \mu \mathrm{M}$ PNU120596 (Tocris). After 5-minute preincubation of the peptides, the mixture of ACh with peptide was applied and fluorescence was recorded every 2 seconds for 3 minutes (excitation/ emission: $485 / 535 \mathrm{~nm}$ ) using a Hidex Sence multimodal microplate reader (Hidex). Responses were measured as the peak intensity minus the basal fluorescence level and were expressed as a percentage of the maximal response to $30 \mu \mathrm{M}$ ACh. Controls were run in the presence of $4 \mu \mathrm{M} \alpha$-cobratoxin. All data files were analyzed using Hidex Sence software (Hidex) and OriginPro 8 software (OriginLab) for statistical analysis. All $\mathrm{IC}_{50} / \mathrm{EC}_{50}$ curves presented in this article were fitted with the following dose-response equation: $y=A 1+(A 2-A 1) / 1+10^{(\log x 0-x) \times p}$

\section{Results}

Synthesis and Characterization of Arginine-Containing Peptides. All arginine-containing peptides (Fig. 1A) were obtained by standard methods of solid-phase peptide synthesis using the Fmoc strategy and were purified by reverse phase HPLC. Their structures were confirmed by electrospray ionization-MS (Supplemental Fig. 1), with experimental values of the masses being in full accordance with the theoretical values (Supplemental Table 1).

Analysis of Competition of Arginine-Containing Peptides with Radioiodinated $\alpha$ Bgt for Binding to $\alpha 9$ LBD, A. californica and L. stagnalis AChBPs, $T$. californica nAChR, and Human $\alpha 7$ nAChR. The tests began with the AChBPs, which bind $\alpha$ Bgt and some other snake venom $\alpha$-neurotoxins and $\alpha$-conotoxins, according to biochemical and X-ray data (Celie et al., 2005; Hansen et al., 2005; Ulens et al., 2006; Dutertre et al., 2007; Lin et al., 2016b). None of the peptides (at a concentration of up to
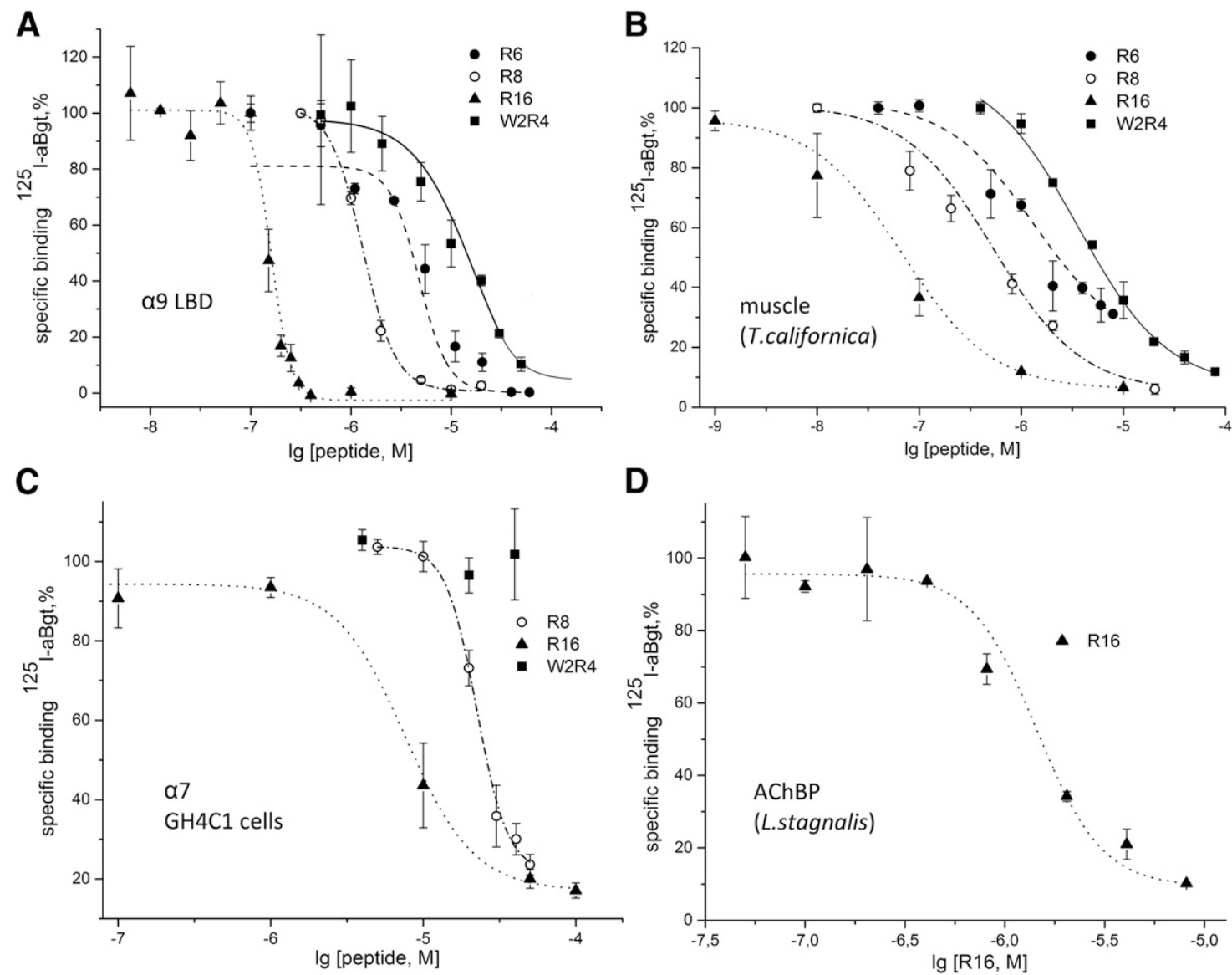

Fig. 2. Results of competitive radioligand assays. (A and B) Competition of ${ }^{125} \mathrm{I}$ - $\alpha$ Bgt with arginine peptides R6 (black circles), R8 (white circles), R16 (black triangles), and W2R4 (black squares) for binding to $\alpha 9 \mathrm{LBD}$ (A) and T. californica nAChR (B). (C) Competition of ${ }^{125} \mathrm{I}-\alpha \mathrm{Bgt}$ with peptides R8 (white circles), R16 (black triangles), and W2R4 (black squares) for binding to human $\alpha 7$ nAChR expressed in the GH4C1 cell line. (D) Competition of ${ }^{125} \mathrm{I}-\alpha$ Bgt with arginine oligomer R16 (black triangles) for binding to L. stagnalis AChBP. Each data point is the mean of two to four independent experiments \pm S.D. The respective $\mathrm{IC}_{50}$ values are presented in Table 2. 
$40 \mu \mathrm{M}$ ) interacted with A. californica AChBP. As for L. stagnalis AChBP, no inhibition was observed with oligoarginine peptides containing eight residues or fewer; only a relatively weak inhibition was shown with R16 (Fig. 2D), with an $\mathrm{IC}_{50}$ value in the micromolar range (Table 2). This means that at least relatively long oligoarginine peptides can bind to this nAChR model. We recently demonstrated a competition of ${ }^{125} \mathrm{I}-\alpha$ Bgt with arginine-rich $\alpha$-conotoxin RgIA and $\alpha \mathrm{O}$-conotoxin GeXIVA for binding to another nAChR model, namely to the LBD of the nAChR $\alpha 9$ subunit ( $\alpha 9$ LBD) (Kryukova et al., 2018a). In this work, we checked the interaction of oligoarginines with $\alpha 9$ LBD via their ability to inhibit specific ${ }^{125} \mathrm{I}-\alpha$ Bgt binding (Fig. 2A). No activity was registered for peptides R3 and WR2 at up to $60 \mu \mathrm{M}$, whereas activity increased for the series W2R4, R6, R8, and R16, with values of approximately 15,5 , and $1 \mu \mathrm{M}$ for W2R4, R6, and R8, respectively, and $160 \mathrm{nM}$ for R16 (Table 2).

Next we examined the competition of oligoarginines with ${ }^{125} \mathrm{I}$ - $\alpha$ Bgt for binding to full-size receptors: muscle-type T. californica ray $\mathrm{nAChR}$ (Fig. 2B) or human $\alpha 7 \mathrm{nAChR}$ (Fig. 2C). As in the two preceding cases with L. stagnalis AChBP and $\alpha 9$ LBD, there was virtually no inhibition of ${ }^{125} \mathrm{I}$ $\alpha$ Bgt binding to these receptors by tripeptides R3 or WR2 (Table 2). Hexapeptides R6 and W2R4 revealed a certain selectivity for the Torpedo nAChR, with low micromolar $\mathrm{IC}_{50}$ values and almost no binding to the $\alpha 7$ receptor. The affinity toward the Torpedo nAChR dramatically increased from $0.4 \mu \mathrm{M}$ for R8 to $36 \mathrm{nM}$ for R16, but an increase was not so dramatic for $\alpha 7 \mathrm{nAChR}\left(\mathrm{IC}_{50}=\right.$ approximately 8-22 $\left.\mu \mathrm{M}\right)$.

Analysis of the Interaction of Oligoarginine Peptides with nAChRs by Two-Electrode Voltage-Clamp Electrophysiology or Calcium Imaging. We used twoelectrode voltage-clamp electrophysiology to analyze the effects of oligoarginines on mouse $\alpha 1_{2} \beta 1 \varepsilon \delta$ muscle nAChRs (Fig. 3B), human neuronal $\alpha 3 \beta 2 \mathrm{nAChRs} \mathrm{(Fig.} \mathrm{3A),} \mathrm{and} \alpha 9 \alpha 10$ nAChRs expressed in Xenopus oocytes (Fig. 3D; see also Supplemental Fig. 2, A, B, and D). In general, the same tendency was observed in their activities as in competition with ${ }^{125} \mathrm{I}-\alpha$ Bgt: there was no decrease of current amplitudes by tripeptides R3 and WR2, whereas all examined receptors were inhibited by hexapeptides R6 and W2R4 at low micromolar concentrations (Table 3). Interestingly, incorporation of two Trp residues made the affinity of the respective hexapeptide several times higher, compared with R6, for muscle and $\alpha 3 \beta 2$ receptors, except $\alpha 9 \alpha 10 \mathrm{nAChR}$ : against the latter, R6 with an $\mathrm{IC}_{50}$ of $0.3 \mu \mathrm{M}$ was 20 -fold more active.

Peptide R16 showed the highest affinity toward $\alpha 9 \alpha 10$ $\mathrm{nAChR}$, with an $\mathrm{IC}_{50}$ of $120 \mathrm{nM}$, slightly low efficacy for blocking muscle receptors $\left(\mathrm{IC}_{50}=160 \mathrm{nM}\right)$, and the lowest activity in the micromolar range toward $\alpha 3 \beta 2 \mathrm{nAChRs}$. Interestingly, R8 against the muscle and $\alpha 3 \beta 2$ nAChRs was about 50- and 8-fold weaker than R16, but it had the highest affinity of $44 \mathrm{nM}$ for $\alpha 9 \alpha 10 \mathrm{nAChR}$ (Table 3). Since the affinity of R8 for all other tested nAChRs was 100-fold lower, this compound can be considered as a relatively selective antagonist of $\alpha 9 \alpha 10 \mathrm{nAChR}$.

We also studied the action of oligoarginines on the $\alpha 7$ nAChR expressed in Neuro2a cells using calcium imaging in the presence of positive allosteric modulator PNU 120596, essentially as described in Shelukhina et al. (2017). The results (Fig. 3C; Table 3; Supplemental Fig. 2C) agree in general with what was obtained for other receptors heterologously expressed in Xenopus oocytes (i.e., no activity for tripeptides, and $\mathrm{IC}_{50}$ values for all other compounds being in the low micromolar range). The most interesting result here was the relatively high activity of hexapeptide W2R4 $\left(\mathrm{IC}_{50}=\right.$ $1 \mu \mathrm{M})$ in contrast with its low affinity toward the same receptor in the competition with ${ }^{125} \mathrm{I}-\alpha$ Bgt (see Table 2), suggesting its binding outside the orthosteric site.

To obtain more detailed information on the binding mode of W2R4 peptide to $\alpha 7 \mathrm{nAChR}$, we performed a series of calcium imaging experiments in which we changed the agonist concentration. We built a dose-response curve to ACh for $\alpha 7$ $\mathrm{nAChR}$ in the absence and presence of $1 \mu \mathrm{M}$ W2R4; this revealed the right shift of the $\mathrm{EC}_{50}$ value from $1.53 \mu \mathrm{M}$ (95\% CI, 1.21-2.46) to $10.1 \mu \mathrm{M}(95 \% \mathrm{CI}, 4.09-27.3)$, with a reliable decreasing amplitude of maximum response from $95 \% \pm 4.7 \%$ to $73.5 \% \pm 4.7 \%$ (Fig. $4 \mathrm{~A}$; Supplemental Fig. 2E), hinting at a possible noncompetitive mode of inhibition.

For comparison, we evaluated in a similar way the current inhibition mode in additional electrophysiological experiments for peptide $\mathrm{R} 8$ toward the $\alpha 9 \alpha 10$ receptor, taking into consideration its highest affinity and the specificity toward this receptor subtype compared with other oligoarginines (Table 3). The dose-response curves for $\alpha 9 \alpha 10 \mathrm{nAChR}$ showed that R8 at $50 \mathrm{nM}$ did not markedly modify the $\mathrm{EC}_{50}$ value (Fig. 4B; Supplemental Fig. $2 \mathrm{~F}$ ) from $19.2 \mu \mathrm{M}$ (95\% CI, 14.02-26.35) to $36.9 \mu \mathrm{M}(95 \%$ CI, 21.1-64.5) and markedly reduced the maximum current amplitude from $102.9 \% \pm 3.9 \%$ to $18.8 \% \pm 2.6 \%$, which is a typical behavior of noncompetitive inhibitors.

A noncompetitive mechanism of R8 action on $\alpha 9 \alpha 10 \mathrm{nAChR}$ could also be suggested from our next experiment. Simultaneous coapplication of $120 \mathrm{nM}$ R8 with $30 \mu \mathrm{M}$ ACh had a little effect on the peak amplitude but led to prominent reduction of the ACh-evoked net charge (Fig. 4C). Herewith, preincubation with $\mathrm{R} 8$ peptide for 5 minutes resulted in a dramatic reduction of the peak amplitude of the ACh-evoked ion current (Fig. 4D).

TABLE 2

Results of the ${ }^{125} \mathrm{I}-\alpha$ Bgt competition assay with oligoarginine peptides

Data are presented as $\mathrm{IC}_{50}$ values $(95 \% \mathrm{CIs})$, and each point is the mean of two measurements for each concentration in two or three independent experiments.

\begin{tabular}{|c|c|c|c|c|c|}
\hline \multirow{2}{*}{ Peptide } & \multicolumn{5}{|c|}{$\mathrm{IC}_{50}(95 \% \mathrm{CI})$} \\
\hline & T. californica $\mathrm{nAChR}$ & $\alpha 7 \mathrm{nAChR}$ & $\alpha 9$ LBD & L. stagnalis $\mathrm{AChBP}$ & A. californica $\mathrm{AChBP}$ \\
\hline & \multicolumn{5}{|c|}{$\mu M$} \\
\hline WR2 & $>20$ & $>40$ & $>60$ & $>40$ & $>40$ \\
\hline W2R4 & $4.18(3.32-5.26)$ & $>40$ & $15.5(12.5-19.1)$ & $>40$ & $>40$ \\
\hline R6 & $1.21(0.94-1.56)$ & $>40$ & $4.75(3.31-6.82)$ & $>40$ & $>40$ \\
\hline $\mathrm{R} 8$ & $0.401(0.376-0.442)$ & $22.4(20.7-24.2)$ & $1.31(1.20-1.43)$ & $>20$ & $>40$ \\
\hline
\end{tabular}


A

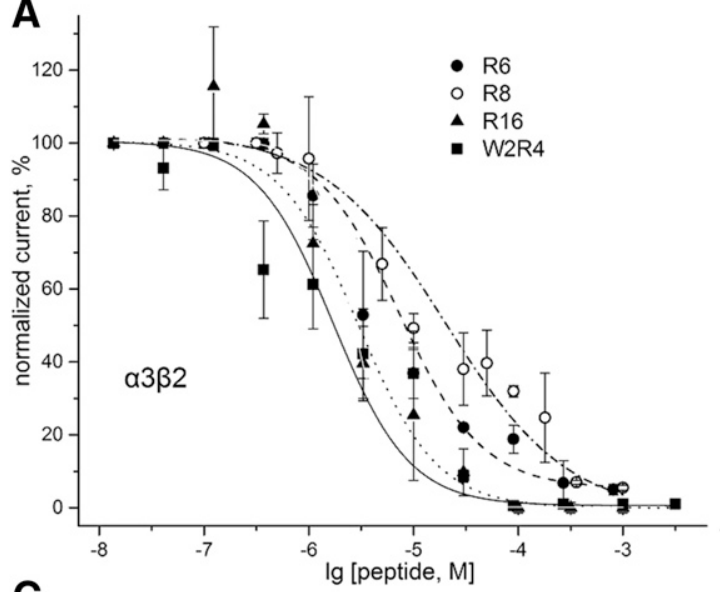

C

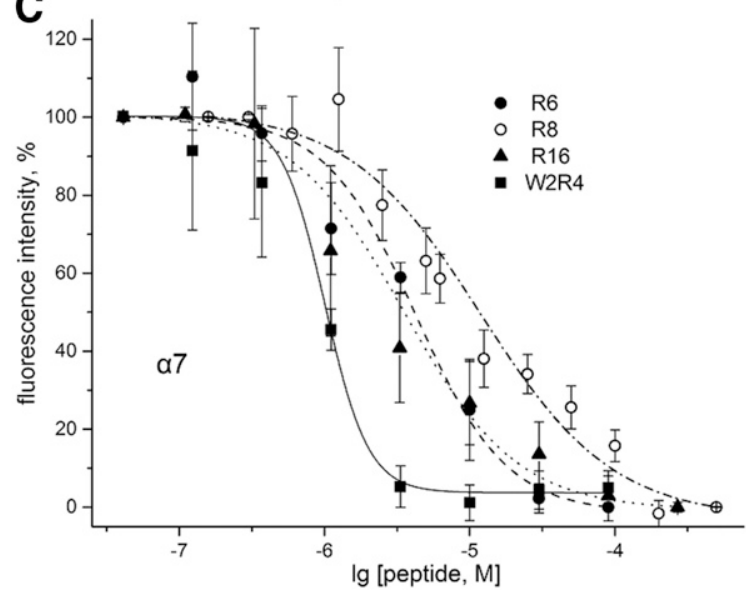

B

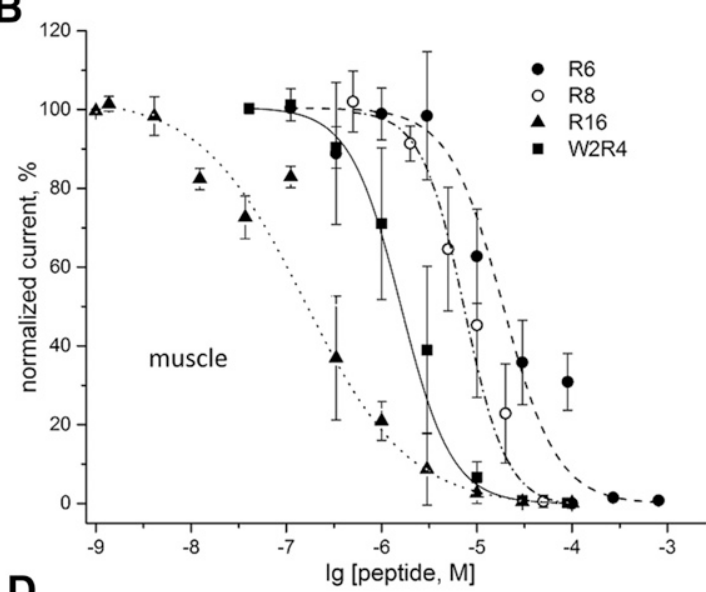

D

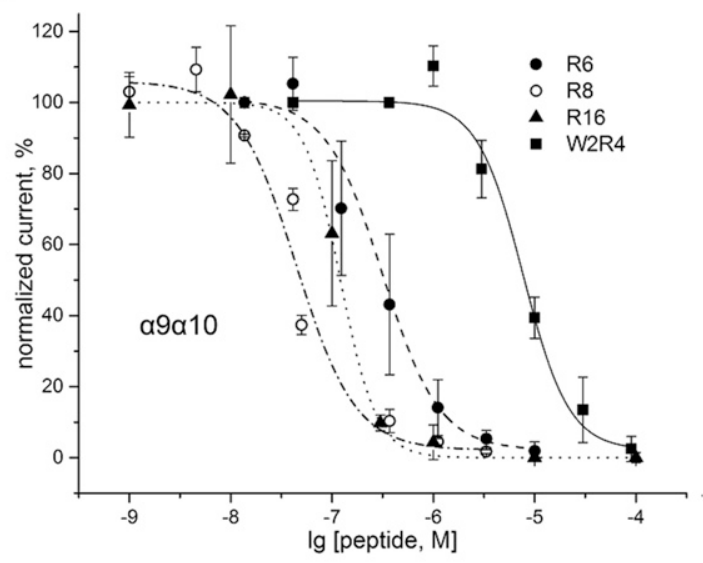

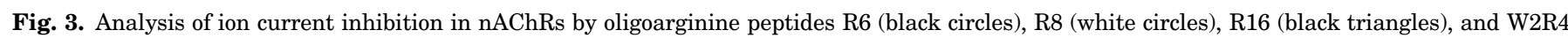

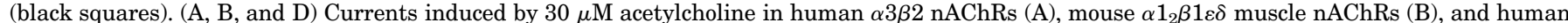

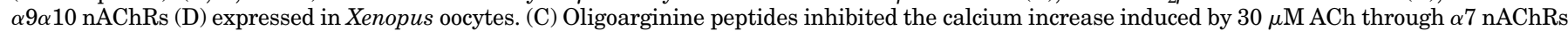

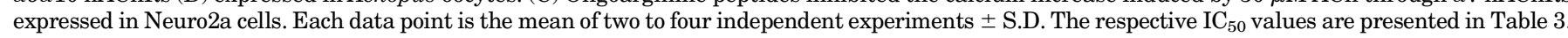

However, the increase in the ACh concentration from 30 to $270 \mu \mathrm{M}$ did not cause a substantial effect on the relative degree of inhibition both at simultaneous coapplication of peptide with ACh (Fig. 4, C and E) and at its preincubation (Fig. 4, D and F), confirming a noncompetitive mechanism of inhibition.

We attempted to characterize this peptide binding site and investigated the effect of membrane potential on $\mathrm{R} 8$ activity. The degree of $\alpha 9 \alpha 10 \mathrm{nAChR}$ inhibition showed a strong dependence on membrane potential: $120 \mathrm{nM}$ R8 reduced the amplitude of ACh-evoked ion current by more than twice at a negative potential $(-120$ and $-60 \mathrm{mV})$ but had a very little effect on it at positive holding potential $(+40$ and $+60 \mathrm{mV})$ (Fig. 5A), suggesting possible action on the receptor ion pore. We also analyzed the voltage-current relationship of $\alpha 9 \alpha 10$ nAChR. Voltage ramp was performed during application of $10 \mu \mathrm{M}$ ACh. Preincubation with $120 \mathrm{nM}$ R8 (near its $\mathrm{IC}_{50}$ value) noticeably shifted the reversal potential from -22 to $+5 \mathrm{mV}$ (Fig. 5B, solid and dashed lines). In contrast, interaction with $\alpha$-cobratoxin, a classic competitive antagonist, did not produce any reversal potential shift (Fig. 5B, dotted line). The reversal potential shift most likely arises from the R8 binding in $\alpha 9 \alpha 10 \mathrm{nAChR}$ at a site situated near the ion pore.

TABLE 3

Results of the two-electrode voltage-clamp recording and calcium imaging assay of oligoarginine peptides

Data are presented as $\mathrm{IC}_{50}$ values $(95 \% \mathrm{CIs})(n=2-6)$.

\begin{tabular}{|c|c|c|c|c|}
\hline \multirow{2}{*}{ Peptide } & \multicolumn{4}{|c|}{$\mathrm{IC}_{50}(95 \% \mathrm{CI})$} \\
\hline & Muscle & $\alpha 3 \beta 2$ & $\alpha 9 \alpha 10$ & $\alpha 7$ \\
\hline & \multicolumn{4}{|c|}{$\mu M$} \\
\hline R3 & $>50$ & $>50$ & $>50$ & $>50$ \\
\hline WR2 & $>50$ & $>50$ & $>50$ & $>50$ \\
\hline W2R4 & $1.60(1.22-2.11)$ & $1.71(0.688-4.24)$ & $7.71(5.46-10.90)$ & $1.01(0.91-1.12)$ \\
\hline $\mathrm{R} 6$ & $19.1(9.16-40.00)$ & $7.59(5.25-10.9)$ & $0.316(0.181-0.552)$ & $4.24(3.45-5.22)$ \\
\hline $\mathrm{R} 8$ & $7.37(4.87-11.20)$ & $20.3(9.08-45.5)$ & $0.044(0.026-0.075)$ & $11.9(8.45-16.8)$ \\
\hline R16 & $0.157(0.085-0.284)$ & $2.61(1.58-4.34)$ & $0.12(0.093-0.159)$ & $3.53(2.17-5.72)$ \\
\hline
\end{tabular}



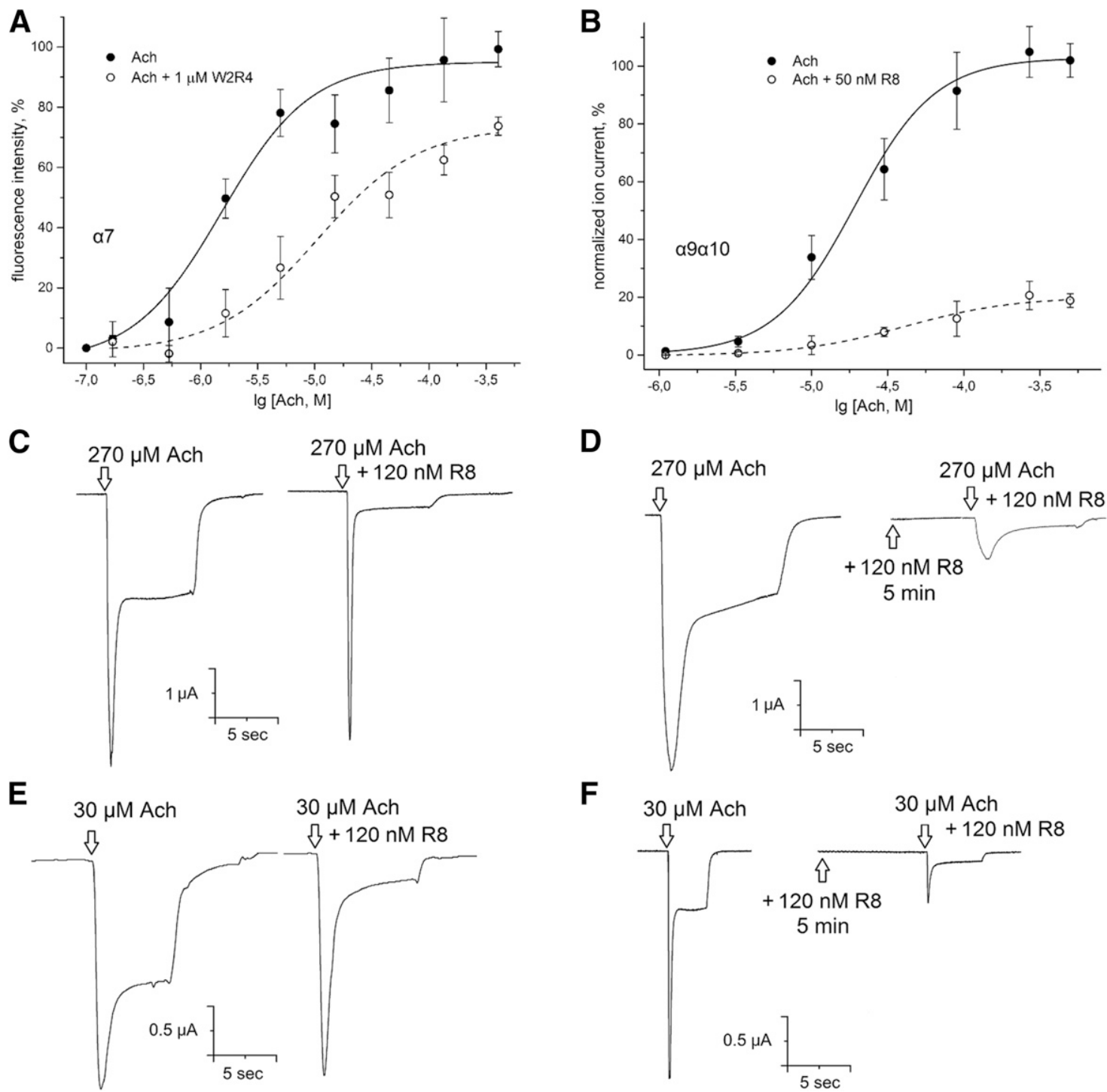

Fig. 4. (A and B) Shifts of ACh dose-response curves on $\alpha 7 \mathrm{nAChR}$ expressed in Neuro2a cells under the influence of $1 \mu \mathrm{M} \mathrm{W} 2 \mathrm{R} 4$ (A) and on $\alpha 9 \alpha 10 \mathrm{nAChR}$ expressed in Xenopus oocytes under the influence of $50 \mathrm{nM}$ R8 (B). The $\mathrm{EC}_{50}$ value for the $\alpha 7$ receptor under the influence of W2R4 was essentially increased from $1.53 \mu \mathrm{M}(95 \% \mathrm{CI}, 1.21-2.46)$ to $10.1 \mu \mathrm{M}$ (95\% CI, 4.09-27.3). The $\mathrm{EC}_{50}$ value for the $\alpha 9 \alpha 10$ receptor under the influence of R8 was changed slightly from $19.2 \mu \mathrm{M}(95 \% \mathrm{CI}, 14.0-26.3)$ to $36.9 \mu \mathrm{M}(95 \% \mathrm{CI}, 21.1-64.5)$. Because of decreasing maximum current amplitude in both cases, these results suggest the noncompetitive mode of antagonism. (C and E) Ion current traces induced in Xenopus oocytes expressed $\alpha 9 \alpha 10 \mathrm{nAChR}$ by simultaneous application of 30 or $270 \mu \mathrm{M}$ ACh with $120 \mathrm{nM}$ R8, together with control traces induced by 30 or $270 \mu \mathrm{M}$ ACh. Current amplitude was not changed under the influence of R8 but net charge was noticeably decreased. (D and F) Five-minute preincubation of the oocyte with $120 \mathrm{nM}$ R8 was followed by application of 30 or $270 \mu \mathrm{M}$ ACh with $120 \mathrm{nM}$ R8. Both amplitude and net charge were decreased considerably. The lack of immediate R8 effect on amplitude can be explained by its slow binding kinetics. The independence of inhibition mode on ACh concentration indicates the noncompetitive nature of this interaction.

Analysis of Interaction of CPs with nAChRs. After finding the cholinergic effects with the oligoarginine peptides, we hypothesized that other CPs also might show antagonistic properties toward nAChRs and we investigated this with three compounds (see Fig. 1B) synthesized for intracellular gene delivery (Memanishvili et al., 2014; Zavradashvili et al., 2014, 2019). Binding tests showed competition of $2 \mathrm{ApdC}$ and $8 \mathrm{R} 3$ with $^{125} \mathrm{I}-\alpha$ Bgt for binding to human $\alpha 7 \mathrm{nAChR}$ on GH4C1 cells (Fig. 6A). Next, we demonstrated the ability of compounds $2 \mathrm{ApdC}$ and $8 \mathrm{R} 3$ to inhibit $\mathrm{ACh}$-induced calcium entry through human $\alpha 7 \mathrm{nAChR}$, whereas $t \mathrm{ES}-\mathrm{ED}-\mathrm{R}(\mathrm{Me})$ did not show any activity at a concentration up to $100 \mathrm{mg} / \mathrm{l}$ (Fig. 6B; Table 4). Interestingly, 2ApdC and $t$ ES-ED-R(Me) in electrophysiological experiments on Xenopus oocytes showed the properties of the mouse muscle $\alpha 1_{2} \beta 1 \varepsilon \delta \mathrm{nAChR}$ antagonists (Fig. 6C; Table 4). It should be noted that these synthetic CPs are the mixtures of fractions with different molecular weights (disperse systems), which makes it impossible to assess their activity in molar units and makes as operate only in units of milligrams per liter.

\section{Discussion}

This work presents oligoarginine peptides as a new group of nAChR inhibitors. Synthesis of these compounds was not a consequence of a comprehensive in silico analysis but originated from our long studies on $\alpha$-conotoxins, in which Arg residues were found to be important for efficient binding 
A

$10 \mu \mathrm{M}$ Ach+120 nM R8
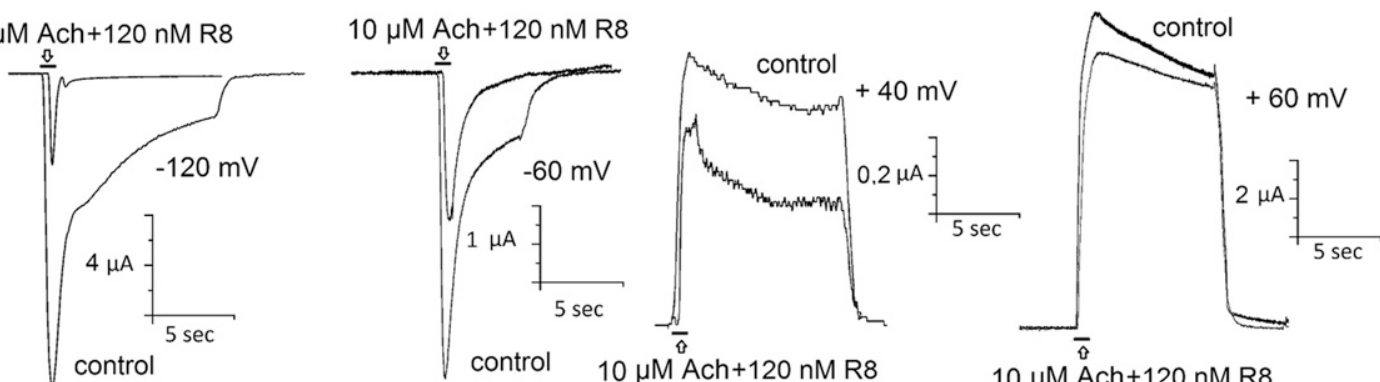

B

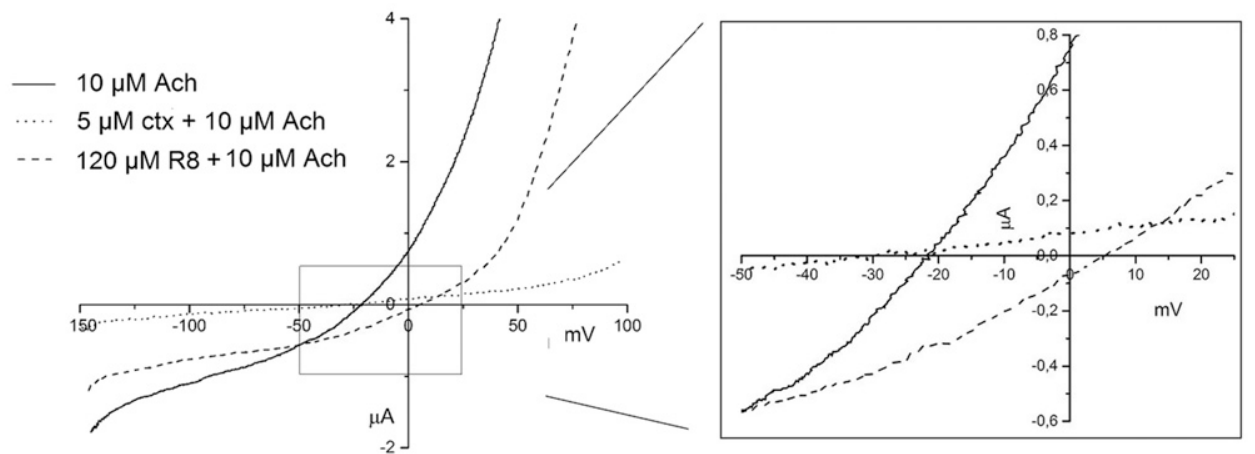

Fig. 5. (A) The degree of inhibition of $\alpha 9 \alpha 10 \mathrm{nAChR}$ by R8 is dependent on holding potential. Current was evoked by $10 \mu \mathrm{M}$ ACh with the addition of $120 \mathrm{nM}$ R8 after 5-minute incubation of $120 \mathrm{nM}$ R8 with $\alpha 9 \alpha 10 \mathrm{nAChR}$. The oocyte was held at $-120,-60,+40$, and $+60 \mathrm{mV}$. (B) Voltage-current relationship of $\alpha 9 \alpha 10 \mathrm{nAChR}$. The positive control current (solid line) was induced by $10 \mu \mathrm{M}$ ACh. The second ramp (dashed line) was performed during exposure to $10 \mu \mathrm{M}$ ACh after 5-minute incubation with $120 \mathrm{nM}$ R8. The negative control ramp (dotted line) was evoked by $10 \mu \mathrm{M}$ ACh after 5 -minute incubation with $1 \mu \mathrm{M}$ cobratoxin. Cobratoxin, as a classic competition antagonist, had no effect on reversal potential, whereas R8 shifted this potential and modified the channel's ion permeability in a potential-dependent manner.

to various nAChR subtypes (Kasheverov et al., 2006, 2011, 2016; Utkin et al., 2012). In particular, this work was also stimulated by the recent discovery of $\alpha \mathrm{O}$-conotoxin GeXIVA, which contains the sequence RRRR and has high selectivity for $\alpha 9 \alpha 10 \mathrm{nAChRs}$ (Luo et al., 2015; Li et al., 2016; Zhangsun et al., 2017).

In this study, we showed that oligoarginines are nAChR inhibitors, based on experiments with $T$. californica muscletype nAChR, mouse muscle nAChR, and human neuronal $\alpha 3 \beta 2, \alpha 7$, and $\alpha 9 \alpha 10 \mathrm{nAChRs}$. Similarly to embracing a series of $\mathrm{nAChRs}$ and their models, we used a combination of methods to reliably prove the interaction of oligoarginines with the tested targets. First, binding was revealed via competition with radioiodinated ${ }^{125} \mathrm{I}-\alpha$ Bgt for attaching to the receptors or their models (see Fig. 2; Table 2). Second, competition with $\alpha$ Bgt was reflected in the inhibition of functional responses in all analyzed receptors, as shown by two-electrode voltage-clamp electrophysiology and calcium imaging (see Figs. 3 and 4; Table 3).

What are the main findings? First, this study shows that two or three Arg residues (in R3 or WR2) are insufficient for interaction. Binding started with the hexapapetides R6 and
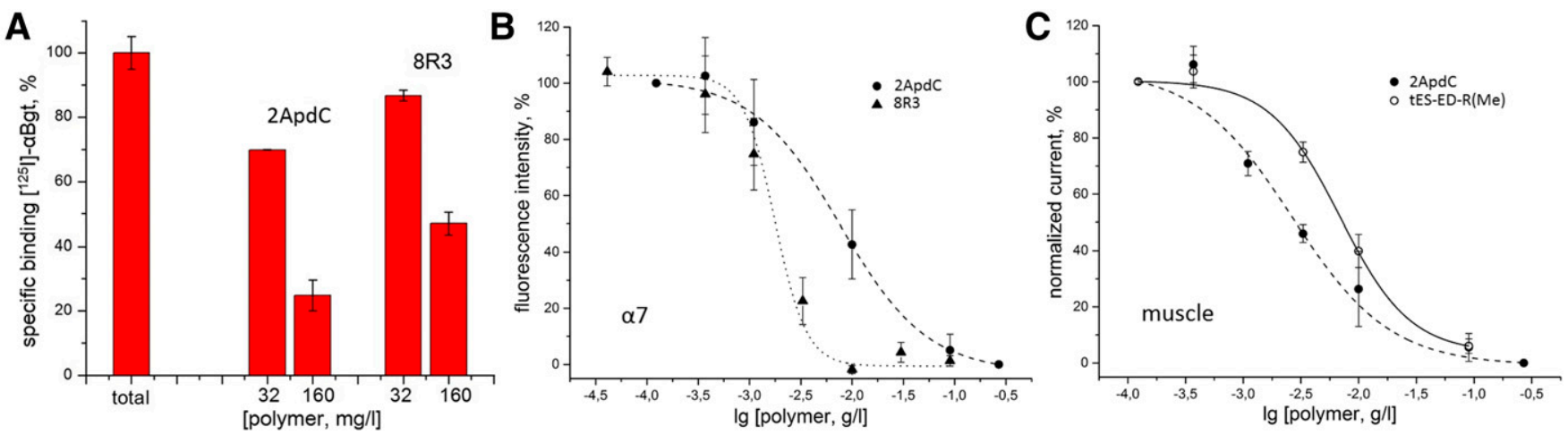

Fig. 6. (A) Competition of CPs $2 \mathrm{ApdC}$ and $8 \mathrm{R} 3$ with ${ }^{125} \mathrm{I}-\alpha$ Bgt for binding to the human $\alpha 7 \mathrm{nAChR}$ in the GH4C1 cell line. tES-ED-R(Me) did not show inhibition of binding ${ }^{125} \mathrm{I}-\alpha$ Bgt to $100 \mathrm{mg} / \mathrm{l}$. (B) Inhibition of the intracellular calcium concentration increase induced by ACh in human $\alpha 7 \mathrm{nAChR}$ expressed in Neuro2a cells by 2ApdC (black circles) and 8R3 (black triangles). (C) Inhibition of ion currents induced in the mouse muscle $\alpha 1_{2} \beta 1 \varepsilon \delta$ receptor expressed in $X$. laevis oocytes by 2ApdC (black circles) and $t$ ES-ED-R(Me) (white circles). Each data point is the mean of two to four independent experiments \pm S.D. 
TABLE 4

Results of the two-electrode voltage-clamp recording and calcium imaging assay of CPs.

Data are presented as $\mathrm{IC}_{50}$ values $(95 \% \mathrm{CIs})(n=2-4)$.

\begin{tabular}{lll}
\hline \multirow{2}{*}{ Substance } & \multicolumn{2}{c}{$\mathrm{IC}_{50}(95 \% \mathrm{CI})$} \\
\cline { 2 - 3 } & \multicolumn{2}{c}{$\alpha 7$} \\
\hline & \multicolumn{2}{c}{$m g / l$} \\
$t$ ES-ED-R(Me) & $6.86(5.34-8.86)$ & \multicolumn{1}{c}{$>100$} \\
2ApdC & $2.65(1.88-3.74)$ & $7.69(5.83-10.13)$ \\
8R3 & Not determined & $1.77(1.04-3.01)$ \\
\hline
\end{tabular}

W2R4 and became more pronounced with R8 and R16. The measured $\mathrm{IC}_{50}$ values (see Fig. 2; Table 2) for a series of $\mathrm{nAChRs}$ were the first indication that oligoarginines may possess a certain selectivity for distinct $\mathrm{nAChR}$ subtypes, which was then confirmed by the inhibition of $\mathrm{nAChR}$ functional responses (Figs. 3 and 4; Table 3). In the electrophysiology experiments, the most active was R8 at $\alpha 9 \alpha 10$ $\mathrm{nAChR}\left(\mathrm{IC}_{50} 0.04 \mu \mathrm{M}\right)$ and its activity for all other tested nAChRs was 100 -fold lower, showing its moderate selectivity for the $\alpha 9 \alpha 10 \mathrm{nAChR}$.

Of particular interest is the hexapeptide W2R4, which bound with micromolar affinity to the Torpedo $\mathrm{nAChR}$ and $\alpha 9$ LBD but did not compete with ${ }^{125} \mathrm{I}-\alpha$ Bgt for binding to $\alpha 7$ nAChR (Table 2). On the other hand, functional tests on all studied receptors revealed inhibitory activity in the range of 1-8 $\mu \mathrm{M}$, with the highest activity against $\alpha 7 \mathrm{nAChR}$, thus indicating the interaction with the latter receptor at the site not overlapping that for $\alpha$ Bgt.

In our recent work on low molecular weight compounds (Kudryavtsev et al., 2018; Spirova et al., 2019), $\alpha$-conotoxins (Kudryavtsev et al., 2015; Kasheverov et al., 2016; Kryukova et al., 2018a), and human Ly6 proteins (Lyukmanova et al., 2016; Durek et al., 2017), we found that some of them can bind to the orthosteric or allosteric sites of nAChRs. Here we did not plan a detailed investigation of the mechanism of oligoarginine action, but we made exceptions for $\mathrm{R} 8$ and W2R4.

Since R8 shows moderate selectivity for $\alpha 9 \alpha 10 \mathrm{nAChR}$, we analyzed the effects of $\mathrm{R} 8$ on the receptor currents in more detail. The voltage-clamp experiments showed that $\mathrm{R} 8 \mathrm{did}$ not considerably modify the $\mathrm{EC}_{50}$ value of $\mathrm{ACh}$ for the human $\alpha 9 \alpha 10$ nAChR (Fig. 4B) but it reduced the maximum current amplitude. In addition, a degree of $\alpha 9 \alpha 10 \mathrm{nAChR}$ inhibition by $\mathrm{R} 8$ did not decrease with the increased ACh concentration (Fig. 4, C-F). This allowed us to assume a mixed, seminoncompetitive mode of inhibition and suggests the existence of an auxiliary binding site in addition to the orthosteric site revealed by the competition assay. The voltage-clamp experiments with a change in membrane potential showed that inhibition of $\alpha 9 \alpha 10 \mathrm{nAChR}$ by R8 depends on the membrane potential (Fig. 5A). To note, a classic nAChR competitive inhibitor $\alpha$-cobratoxin decreases the amplitude of ion current regardless of the potential polarity, whereas $\mathrm{R} 8$ decreases the inward current recorded under the negative potential more strongly than the outward current recorded under positive potential (Fig. 5B). In addition, $\alpha$-cobratoxin does not modify the value of reverse potential, whereas $R 8$ substantially shifts it. Thus, we suppose that the additional allosteric binding site for positively charged $\mathrm{R} 8$ is most likely near the nAChR channel moiety, where a number of negatively charged amino acid residues are situated.
In another example of probable binding beyond the orthosteric sites, W2R4 peptide showed no competition with ${ }^{125} \mathrm{I}$ $\alpha$ Bgt but inhibited the $\mathrm{Ca}^{2+}$ entrance through $\alpha 7 \mathrm{nAChR}$. In addition, imaging experiments showed a decrease in maximum current amplitude under the influence of W2R4. In view of a lack of competition with ${ }^{125} \mathrm{I}-\alpha \mathrm{Bgt}$, the noncompetitive binding mode seems to be a plausible explanation for these observations.

We decided to investigate whether CPs can interact with nAChRs. CPs can form electrostatic complexes with anionic biomolecules including nucleic acids and are of interest as carriers of biologically active compounds. Antimicrobial, antioxidant, antitumor, and anti-inflammatory properties make CPs promising for therapeutic purposes (Moroson and Rotman, 1975; Samal et al., 2012). Thus, activity against nAChRs was tested for three compounds (see Fig. 6; Table 4) synthesized for intracellular gene delivery (Memanishvili et al., 2014; Zavradashvili et al., 2014, 2019). We detected competition of 2ApdC and 8R3 but not of tES-ED-R(Me) with ${ }^{125} \mathrm{I}-\alpha \mathrm{Bgt}$ for binding to $\alpha 7 \mathrm{nAChR}$ on $\mathrm{GH} 4 \mathrm{C} 1$ cells. Compounds 2ApdC and 8R3 inhibited ACh-induced calcium entry through $\alpha 7 \mathrm{nAChR}$. In electrophysiological experiments on Xenopus oocytes, 2ApdC and tES-ED-R(Me) behaved as antagonists of muscle nAChRs.

The discovered capacity of oligoarginines, their modified forms, and the ability of CPs to interact with nAChRs may have positive and negative consequences. Some examples include lung cancer cells when such nAChR subtypes such as $\alpha 7$ should be suppressed (Spindel, 2016) and where oligoarginines may play both a transporter and inhibitor role. On the other hand, when there is a need to activate nAChRs, such as in the case of immune cells in inflammatory conditions (Zakrzewicz et al., 2017), the inhibition may be undesirable. The most serious outcome might be a block of muscle nAChRs leading to respiratory arrest. Therefore, possible cholinergic side effects of therapeutic application of oligoarginine peptides and CPs should be taken into consideration.

\section{Acknowledgments}

The authors thank Prof. S. Luo (Hainan University, People's Republic of China) for A. californica and L. stagnalis AChBPs.

\section{Authorship Contributions}

Participated in research design: Lebedev, Kryukova, Kudryavtsev, Kasheverov, Zouridakis, Tsetlin.

Conducted experiments: Lebedev, Kryukova, Ivanov, Egorova, Timofeev, Spirova, Tufanova, Siniavin, Zavradashvili, Iagorashvili.

Performed data analysis: Lebedev, Kryukova.

Wrote or contributed to the writing of the manuscript: Lebedev, Kudryavtsev, Kasheverov, Katsarava, Tzartos, Tsetlin.

Note Added in Proof-A typo was found in the RFBR grant number which supports I.E.K in the Fast Forward version published September 6, 2019. The funding footnote has now been corrected.

\section{References}

Azam L and McIntosh JM (2009) Alpha-conotoxins as pharmacological probes of nicotinic acetylcholine receptors. Acta Pharmacol Sin 30:771-783.

Biswas S, Deshpande PP, Perche F, Dodwadkar NS, Sane SD, and Torchilin VP (2013) Octa-arginine-modified pegylated liposomal doxorubicin: an effective treatment strategy for non-small cell lung cancer. Cancer Lett 335:191-200.

Bourne Y, Talley TT, Hansen SB, Taylor P, and Marchot P (2005) Crystal structure of a Cbtx-AChBP complex reveals essential interactions between snake alphaneurotoxins and nicotinic receptors. EMBO J 24:1512-1522.

Celie PH, Kasheverov IE, Mordvintsev DY, Hogg RC, van Nierop P, van Elk R, van Rossum-Fikkert SE, Zhmak MN, Bertrand D, Tsetlin V, et al. (2005) Crystal 
structure of nicotinic acetylcholine receptor homolog AChBP in complex with an $\alpha$-conotoxin PnIA variant. Nat Struct Mol Biol 12:582-588.

Celie PH, van Rossum-Fikkert SE, van Dijk WJ, Brejc K, Smit AB, and Sixma TK (2004) Nicotine and carbamylcholine binding to nicotinic acetylcholine receptors as studied in AChBP crystal structures. Neuron 41:907-914.

Changeux JP (2012) The nicotinic acetylcholine receptor: the founding father of the pentameric ligand-gated ion channel superfamily. $J$ Biol Chem 287:40207-40215.

Dellisanti CD, Yao Y, Stroud JC, Wang ZZ, and Chen L (2007) Crystal structure of the extracellular domain of $\mathrm{nAChR} \alpha 1$ bound to $\alpha$-bungarotoxin at $1.94 \mathrm{~A}$ resolution. Nat Neurosci 10:953-962.

Durek T, Shelukhina IV, Tae HS, Thongyoo P, Spirova EN, Kudryavtsev DS, Kasheverov IE, Faure G, Corringer PJ, Craik DJ, et al. (2017) Interaction of synthetic human SLURP-1 with the nicotinic acetylcholine receptors. Sci Rep 7:16606.

Dutertre S, Nicke A, and Tsetlin VI (2017) Nicotinic acetylcholine receptor inhibitors derived from snake and snail venoms. Neuropharmacology 127:196-223.

Dutertre S, Ulens C, Büttner R, Fish A, van Elk R, Kendel Y, Hopping G, Alewood PF, Schroeder C, Nicke A, et al. (2007) AChBP-targeted $\alpha$-conotoxin correlates distinct binding orientations with $\mathrm{nAChR}$ subtype selectivity. $E M B O J \mathbf{2 6}$ $3858-3867$.

Hansen SB, Sulzenbacher G, Huxford T, Marchot P, Taylor P, and Bourne Y (2005) Structures of Aplysia AChBP complexes with nicotinic agonists and antagonists reveal distinctive binding interfaces and conformations. EMBO J 24:3635-3646.

Jiang QY, Lai LH, Shen J, Wang QQ, Xu FJ, and Tang GP (2011) Gene delivery to tumor cells by cationic polymeric nanovectors coupled to folic acid and the cellpenetrating peptide octaarginine. Biomaterials 32:7253-7262.

Kasheverov IE, Chugunov AO, Kudryavtsev DS, Ivanov IA, Zhmak MN, Shelukhina IV, Spirova EN, Tabakmakher VM, Zelepuga EA, Efremov RG, et al. (2016) Highaffinity $\alpha$-conotoxin PnIA analogs designed on the basis of the protein surface topography method. Sci Rep 6:36848.

Kasheverov IE, Utkin YN, and Tsetlin VI (2009a) Naturally occurring and synthetic peptides acting on nicotinic acetylcholine receptors. Curr Pharm Des 15 $2430-2452$

Kasheverov IE, Zhmak MN, Khruschov AY, and Tsetlin VI (2011) Design of new $\alpha$-conotoxins: from computer modeling to synthesis of potent cholinergic compounds. Mar Drugs 9:1698-1714.

Kasheverov IE, Zhmak MN, Vulfius CA, Gorbacheva EV, Mordvintsev DY, Utkin YN, van Elk R, Smit AB, and Tsetlin VI (2006) Alpha-conotoxin analogs with additional positive charge show increased selectivity towards Torpedo californica and some neuronal subtypes of nicotinic acetylcholine receptors. FEBS J 273:4470-4481.

Kawashima K, Fujii T, Moriwaki Y, Misawa H, and Horiguchi K (2015) Non-neuronal cholinergic system in regulation of immune function with a focus on $\alpha 7 \mathrm{nAChRs}$. Int Immunopharmacol 29:127-134.

Kryukova EV, Ivanov IA, Lebedev DS, Spirova EN, Egorova NS, Zouridakis M, Kasheverov IE, Tzartos SJ, and Tsetlin VI (2018a) Orthosteric and/or allosteric binding of $\alpha$-conotoxins to nicotinic acetylcholine receptors and their models. Mar Drugs 16:460.

Kudryavtsev DS, Shelukhina IV, Son LV, Ojomoko LO, Kryukova EV, Lyukmanova EN, Zhmak MN, Dolgikh DA, Ivanov IA, Kasheverov IE, et al. (2015) Neurotoxins from snake venoms and $\alpha$-conotoxin ImI inhibit functionally active ionotropic $\gamma$-aminobutyric acid (GABA) receptors. J Biol Chem 290:22747-22758.

Kudryavtsev DS, Spirova EN, Shelukhina IV, Son LV, Makarova YV, Utkina NK, Kasheverov IE, and Tsetlin VI (2018) Makaluvamine G from the marine sponge Zyzzia fuliginosa inhibits muscle nAChR by binding at the orthosteric and allosteric sites. Mar Drugs 16:E109.

Lebbe EK, Peigneur S, Wijesekara I, and Tytgat J (2014) Conotoxins targeting nicotinic acetylcholine receptors: an overview. Mar Drugs 12:2970-3004.

Li X, Hu Y, Wu Y, Huang Y, Yu S, Ding Q, Zhangsun D, and Luo S (2016) Antihypersensitive effect of intramuscular administration of $\alpha \mathrm{O}$-conotoxin GeXIVA[1,2] and GeXIVA[1,4] in rats of neuropathic pain. Prog Neuropsychopharmacol Biol Psychiatry 66:112-119.

Lin B, Xu M, Zhu X, Wu Y, Liu X, Zhangsun D, Hu Y, Xiang SH, Kasheverov IE, Tsetlin VI, et al. (2016b) From crystal structure of $\alpha$-conotoxin GIC in complex with Ac-AChBP to molecular determinants of its high selectivity for $\alpha 3 \beta 2 \mathrm{nAChR}$. Sci Rep 6:22349.

Luo S, Zhangsun D, Harvey PJ, Kaas Q, Wu Y, Zhu X, Hu Y, Li X, Tsetlin VI, Christensen S, et al. (2015) Cloning, synthesis, and characterization of $\alpha \mathrm{O}$ conotoxin GeXIVA, a potent $\alpha 9 \alpha 10$ nicotinic acetylcholine receptor antagonist. Proc Natl Acad Sci USA 112:E4026-E4035.

Lyukmanova EN, Shulepko MA, Kudryavtsev D, Bychkov ML, Kulbatskii DS, Kasheverov IE, Astapova MV, Feofanov AV, Thomsen MS, Mikkelsen JD, et al (2016) Human secreted Ly-6/uPAR related protein-1 (SLURP-1) is a selective allosteric antagonist of $\alpha 7$ nicotinic acetylcholine receptor. PLoS One 11:e0149733.

McIntosh JM, Santos AD, and Olivera BM (1999) Conus peptides targeted to specific nicotinic acetylcholine receptor subtypes. Annu Rev Biochem 68:59-88.
Memanishvili T, Zavradashvili N, Kupatadze N, Tugushi D, Gverdtsiteli M, Torchilin VP, Wandrey C, Baldi L, Manoli SS, and Katsarava R (2014) Arginine-based biodegradable ether-ester polymers with low cytotoxicity as potential gene carriers. Biomacromolecules 15:2839-2848.

Morales-Perez CL, Noviello CM, and Hibbs RE (2016) X-ray structure of the human $\alpha 4 \beta 2$ nicotinic receptor. Nature 538:411-415.

Moroson H and Rotman M (1975) Biomedical applications of polycations, in Charged and Reactive Polymers: Polyelectrolytes and Their Applications (Rembaum A and Sélégny E eds) vol 2, pp 187-195, Springer, Dordrecht, The Netherlands.

Nakase I, Takeuchi T, Tanaka G, and Futaki S (2008) Methodological and cellular aspects that govern the internalization mechanisms of arginine-rich cellpenetrating peptides. Adv Drug Del Rev 60:598-607.

Nirthanan S and Gwee MC (2004) Three-finger alpha-neurotoxins and the nicotinic acetylcholine receptor, forty years on. J Pharmacol Sci 94:1-17.

Samal SK, Dash M, Van Vlierberghe S, Kaplan DL, Chiellini E, van Blitterswijk C, Moroni L, and Dubruel P (2012) Cationic polymers and their therapeutic potential. Chem Soc Rev 41:7147-7194.

Shelukhina I, Spirova E, Kudryavtsev D, Ojomoko L, Werner M, Methfessel C, Hollmann M, and Tsetlin V (2017) Calcium imaging with genetically encoded sensor Case12: facile analysis of $\alpha 7 / \alpha 9 \mathrm{nAChR}$ mutants. PLoS One 12:e181936.

Spindel ER (2016) Cholinergic targets in lung cancer. Curr Pharm Des 22:2152-2159.

Spirova EN, Ivanov IA, Kasheverov IE, Kudryavtsev DS, Shelukhina IV, Garifulina AI, Son LV, Lummis SCR, Malca-Garcia GR, Bussmann RW, et al. (2019) Curare alkaloids from Matis dart poison: comparison with d-tubocurarine in interactions with nicotinic, 5-HT3 serotonin and GABAA receptors. PLoS One 14:e210182.

Tsetlin VI and Hucho F (2004) Snake and snail toxins acting on nicotinic acetylcholine receptors: fundamental aspects and medical applications. FEBS Lett 557: 9-13.

Ulens C, Hogg RC, Celie PH, Bertrand D, Tsetlin V, Smit AB, and Sixma TK (2006) Structural determinants of selective alpha-conotoxin binding to a nicotinic acetylcholine receptor homolog AChBP. Proc Natl Acad Sci USA 103:3615-3620.

Utkin YN (2013) Three-finger toxins, a deadly weapon of elapid venom--milestones of discovery. Toxicon 62:50-55.

Utkin YN, Weise C, Kasheverov IE, Andreeva TV, Kryukova EV, Zhmak MN, Starkov VG, Hoang NA, Bertrand D, Ramerstorfer J, et al. (2012) Azemiopsin from Azemiops feae viper venom, a novel polypeptide ligand of nicotinic acetylcholine receptor. J Biol Chem 287:27079-27086.

Vincler M, Wittenauer S, Parker R, Ellison M, Olivera BM, and McIntosh JM (2006) Molecular mechanism for analgesia involving specific antagonism of alpha9alpha10 nicotinic acetylcholine receptors. Proc Natl Acad Sci USA 103:17880-17884.

Wang H, Yu M, Ochani M, Amella CA, Tanovic M, Susarla S, Li JH, Wang H, Yang H, Ulloa L, et al. (2003) Nicotinic acetylcholine receptor alpha7 subunit is an essential regulator of inflammation. Nature 421:384-388.

Yu J, Zhu X, Zhang L, Kudryavtsev D, Kasheverov I, Lei Y, Zhangsun D, Tsetlin V, and Luo S (2018) Species specificity of rat and human $\alpha 7$ nicotinic acetylcholine receptors towards different classes of peptide and protein antagonists. Neuropharmacology 139:226-237.

Zakrzewicz A, Richter K, Agné A, Wilker S, Siebers K, Fink B, Krasteva-Christ G, Althaus M, Padberg W, Hone AJ, et al. (2017) Canonical and novel non-canonical cholinergic agonists inhibit ATP-induced release of monocytic interleukin-1 $\beta$ via different combinations of nicotinic acetylcholine receptor subunits $\alpha 7, \alpha 9$ and $\alpha 10$. Front Cell Neurosci 11:189.

Zavradashvili N, Memenishvili T, Kupatadze N, Baldi L, Shen X, Tugushi D, Wandrey C, and Katsarava R (2014) Cell compatible arginine containing cationic polymer: one-pot synthesis and preliminary biological assessment. Adv Exp Med Biol 807:59-73.

Zavradashvili N, Sarisozen C, Titvinidze G, Otinashvili G, Kantaria T, Tugushi D, Puiggali J, Torchilin V, and Katsarava R (2019) Library of cationic polymers composed of polyamines and arginine as gene transfection agents. ACS Omega 4 2090-2101.

Zhangsun D, Zhu X, Kaas Q, Wu Y, Craik DJ, McIntosh JM, and Luo S (2017) $\alpha$ O Conotoxin GeXIVA disulfide bond isomers exhibit differential sensitivity for various nicotinic acetylcholine receptors but retain potency and selectivity for the human $\alpha 9 \alpha 10$ subtype. Neuropharmacology 127:243-252.

Zouridakis M, Giastas P, Zarkadas E, Chroni-Tzartou D, Bregestovski P, and Tzartos SJ (2014) Crystal structures of free and antagonist-bound states of human $\alpha 9$ nicotinic receptor extracellular domain. Nat Struct Mol Biol 21:976-980.

Address correspondence to: Victor I. Tsetlin, Department of Molecular Neuroimmune Signaling, Shemyakin-Ovchinnikov Institute of Bioorganic Chemistry, Russian Academy of Sciences, Moscow 117997, Russia. E-mail: victortsetlin3f@gmail.com 